Joyful Learning Journal

\title{
HUBUNGAN MOTIVASI DAN DISIPLIN BELAJAR DENGAN HASIL BELAJAR IPS KELAS V
}

\section{Rio Intan Oktaviantoro ${ }^{\bowtie}$ Munisah, Kurniana Bektiningsih}

Jurusan Pendidikan Guru Sekolah Dasar, Fakultas Ilmu Pendidikan, Universitas Negeri Semarang, Indonesia

Info Artikel

Sejarah Artikel:

Diterima Oktober

2017

Disetujui November

2017

Dipublikasikan

Desember 2017

Keywords:

motivation, learning

disciplines, Social

Science learning

outcome.

\begin{abstract}
Abstrak
Siswa yang mempunyai motivasi belajar yang tinggi dan disiplin belajar yang baik maka tinggi pula hasil belajar IPS siswa. Berdasarkan penelitian yang dilakukan di SDN Gugus Patiunus Kecamatan Bonang Kabupaten Demak ditemukan masalah bahwa kurangnya motivasi belajar siswa sehingga disiplin belajar juga kurang dipahami oleh siswa. Hal tersebut menyebabkan hasil belajar yang didapatkan kurang optimal. Tujuan dalam penelitian ini adalah menguji hubungan yang positif dan signifikan antara motivasi dan disiplin belajar dengan hasil belajar IPS siswa kelas V SDN Gugus Patiunus Kecamatan Bonang Kabupaten Demak. Jenis penelitian ini adalah penelitian korelasion al. Dari hasil penelitian diperoleh: 1$)$ hasil 1 hitung $>$ tabel $(0,683>0,244)$ termasuk kategori kuat; 2$)$ hasil 2 hitung $>$ tabel $(0,663>0,244)$ termasuk kategori kuat; 3$)$ hasil 12 hitung $>$ tabel $(0,748>0,244)$ termasuk kategori kuat; 4 ) besar koefisien determinasi $=0,559504$, ini berarti kontribusi motivasi belajar dan disiplin belajar terhadap hasil belajar siswa adalah $55,9 \%$ dan sisanya $44,1 \%$ disumbang oleh faktor-faktor lain. Sehingga dapat disimpulkan bahwa ada hubungan yang positif dan signifikan antara motivasi dan disiplin belajar dengan hasil belajar IPS siswa kelas V SDN Gugus Patiunus Kecamatan Bonang Kabupaten Demak.
\end{abstract}

\begin{abstract}
Students who have high learning motivation and good learning discipline then will be high result student learning ips. Based on research conducted at SDN Gugus Patiunus Subdistrict Bonang, District Demak found the problem that the lack of student learning motivation so that the discipline of learning is also less understood by the students. This results in less than optimal learning outcomes. The purpose of this research is to test the positive and significant relationship between motivation and learning discipline with the learning outcomes of IPS students of grade V SDN Gugus Patiunus Sub- district Bonang District Demak. This type of research is correlational research. From the research results obtained: 1$) 1$ hitung $>$ tabel $(0,683>0,244)$ including strong category; 2$) 2$ hitung $>$ tabel $(0,663>$ $0,244)$ including strong category; 3$) 12$ hitung $>$ tabel $(0,748>0,244)$ including strong category; 4) large coefficient of determination $=0,559504$, this means the contribution of learning motivation and learning discipline to student learning outcomes is $55.9 \%$ and the remaining $44.1 \%$ was contributed by other factors. So it can be concluded that there was a positive and significant relationship between motivation and learning discipline with the results of learning IPS class V SDN Gugus Patiunus Bonang District District Demak.
\end{abstract}

\footnotetext{
Alamat korespondensi: 


\section{PENDAHULUAN}

Indonesia merupakan salah satu negara berkembang di dunia. Sehingga Indonesia berupaya untuk memajukan bangsanya, salah satunya dengan meningkatkan kualitas sumber daya manusia. Sumber daya manusia yang berkualitas diperlukan untuk dapat bersaing di era globalisasi. Pendidikan merupakan sarana utama dalam membentuk dan menciptakan sumber daya manusia yang berkualitas serta mampu berpikir tinggi dan kreatif, namun sering sekali terjadi masalah dalam upaya meningkatkan mutu pendidikan di Indonesia seperti kurangnya motivasi belajar dan disiplin belajar, sehingga cenderung melanggar peraturan -peraturan yang dibuat sekolah. Kurangnya semangat belajar, terlambat datang ke sekolah, tidak membuat tugas yang diberikan, membolos, tidak membawa buku pelajaran, masing-masing individu siswa yang berbeda-beda satu sama lainnya. Motivasi belajar dan disiplin belajar untuk mencapai tujuan pembelajaran yang diharapkan. Sehingga siswa akan lebih siap dalam mengikuti pembelajaran di kelas dan menaati peraturan yang ada di sekolah.

Hasil observasi dan wawancara dengan guru di SDN Gugus Patiunus Kecamatan Bonang Kabupaten Demak guna mendapat informasi awal tentang kondisi proses dan hasil belajar IPS siswa kelas V menunjukkan bahwa perolehan hasil belajar IPS siswa relatif cukup bagus, tetapi masih ditemukan hasil belajar IPS siswa dibawah KKM, siswa satu dengan siswa yang lainnya memiliki karakteristik yang berbeda-beda, terutama dalam menyerap informasi yang disampaikan oleh guru dalam proses pembelajaran, hal tersebut yang menyebabkan hasil belajar setiap siswa berbeda. Siswa yang kurang siap akan merasa kesulitan dalam memahami materi pelajaran terutama pada mata pelajaran IPS karena materi IPS sangat luas. Dalam kegiatan pembelajaran motivasi sangat diperlukan untuk mendorong semangat belajar siswa untuk lebih aktif dan disiplin dalam pembelajaran sehingga akan lebih mudah memahami matreri yang dsampaikan guru.

Sardiman (2016:73) menyatakan bahwa motivasi belajar adalah perubahan energy dalam diri seseorang yang ditandai dengan munculnya feeling dan didahului dengan tanggapan terhadap adanya tujuan. Hamzah B.Uno (2015: 23), motivasi belajar adalah dorongan dari dalam maupun luar diri seseorang untuk mencapai tujuan yang disertai dengan adanya tingkah laku tertentu. Soegeng Prijodarminto (dalam Tulus 2004 : 31). Disiplin sebagai kondisi yang tercipta dan terbentuk melalui proses dari serangkaian perilaku yang menunjukkan nilai-nilai ketaatan, kepatuhan, kesetiaan, keteraturan atau ketertiban. Nilai-nilai tersebut telah menjadi bagian perilaku dalam kehidupannya.

Belajar merupakan suatu proses dimana suatu organisme mengubah perilakunya karena hasil dari pengalaman Gagne (dalam Rifa'I, 2012:66). Jadi belajar adalah suatu proses usaha perubahan tingkah laku yang terjadi melalui latihan dan pengalaman sehingga tingkah laku tersebut mengalami perubahan yang bermanfaat baik bagi diri individu tersebut maupun interaksi dengan lingkungannya. Susanto (2013:5) hasil belajar siswa adalah kemampuan yang diperoleh anak setelah melalui kegiatan belajar.

Beberapa hasil penelitian sejenis tentang motivasi belajar dan disiplin belajar yang menginspirasi peneliti-peneliti lain dilakukan oleh Rachmawati Indah Permata Sari tahun 2014 dengan judul penelitian "Hubungan Motivasi Belajar dengan Hasil Belajar Siswa Pada Mata Pelajaran IPS Kelas IV di SDN 11 Petang Jakarta Timur". Hasil penelitian kontribusi koefisien determinasinya pengaruh variabel motivasi belajar terhadap variabel tersebut adalah sebesar 0,123 atau $12,3 \%$. Jadi, hasil belajar siswa $87,7 \%$ dipengaruhi oleh faktor lain.

Penelitian sejenis tentang motivasi belajar dan disiplin belajar yang menginspirasi peneliti dilakukan oleh Ira Desiyantina, Sultan 
Djasmi dan, Maman Surahman (2015) Universitas Lampung Bandar Lampung dengan judul "Hubungan Antara Disiplin dan Kemandirian Belajar dengan Prestasi Belajar IPS". Hasil penelitian menunjukkan bahwa kajian statistik menggunakan korelasi sederhana, dengan koefisien korelasi $\mathrm{r}$ sebesar 0,820, Terdapat hubungan yang positif antara disiplin belajar dengan prestasi belajar IPS siswa kelas V SD Negeri 3 Gedung Air Kota Bandar Lampung Tahun Pelajaran 2014/2015.

Penelitian yang sejenis tentang motivasi belajar dan disiplin belajar yang menginspirasi peneliti yang dilakukan oleh Sri Susandi, Dibia, dan Nyoman Sudana Pendidikan Guru Sekolah Dasar Universitas Pendidikan Ganesha, yang berjudul " Hubungan Antara Motivasi Belajar Dengan Prestasi Belajar Siswa SD Kelas V Semester Ganjil Di Desa Buruan". Hasil penelitian menunjukan bahwa motivasi belajar terhadap prestasi belajar siswa diperoleh nilai $r$ hitung lebih besar dari pada $\mathrm{r}$ tabel, yang berarti memiliki kontribusi yang signifikan. Sedangkan kontribusi motivasi belajar terhadap prestasi belajar sebesar $29,92 \%$.

Penelitian yang dilakukan oleh Nicholas Odoyo Simba, John Odwar Agak and Eric K. Kabuka tahun 2016 dengna judul "Impact of Discipline on Academic Performance of Pupils in Public Primary Schools in Muhoroni Sub -County, Kenya". Hasil penelitian disiplin memiliki hubungan positif kinerja akademik dengan 37,7\% menjadi di bawah rata-rata kinerja akademik. Tingkat disiplin 5,6\% menjadi disiplin yang rendah, $26,2 \%$ disiplin sedang, $50,6 \%$ disiplin yang tinggi, dan $17,6 \%$ disiplin yang sangat tinggi.

Berdasarkan latar belakang tersebut, peneliti tertarik untuk melakukan penelitian dengan judul "Hubungan Motivasi dan Disiplin Belajar dengan Hasil Belajar IPS Siswa Kelas V SDN Gugus Patiunus Kecamatan Bonang Kabupaten Demak". Rumusan masalah penelitian ini adalah (1) Adakah hubungan yang positif dan signifikan motivasi dengan hasil belajar IPS siswa kelas V SDN Gugus Patiunus Kecamatan Bonang Kabupaten Demak?; (2) Adakah hubungan yang positif dan signifikan disiplin belajar dengan hasil belajar IPS siswa kelas $\mathrm{V}$ SDN Gugus Patiunus Kecamatan Bonang Kabupaten Demak?; (3) Adakah hubungan yang positif dan signifikan motivasi dan disiplin belajar dengan hasil belajar IPS siswa kelas V SDN Gugus Patiunus Kecamatan Bonang Kabupaten Demak? Peneliti ini bertujuan (1) Untuk menguji hubungan yang positif dan signifikan motivasi dengan hasil belajar IPS siswa kelas V SDN Gugus Patiunus Kecamatan Bonang Kabupaten Demak; (2) Untuk menguji hubungan yang positif dan signifikan disiplin belajar dengan hasil belajar IPS siswa kelas V SDN Gugus Patiunus Kecamatan Bonang Kabupaten Demak.; (3) Untuk menguji hubungan motivasi dan disiplin belajar dengan hasil belajar IPS siswa kelas V SDN Gugus Patiunus Kecamatan Bonang Kabupaten Demak.

\section{METODE PENELITIAN}

Jenis penelitian yang digunakan adalah penelitian korelasional atau penelitian untuk mengetahui tingkat hubungan antara dua variabel atau lebih. Populasi penelitian ini adalah siswa kelas V SDN Gugus Patiunus Kecamatan Bonang Kabupaten Demak. Teknik pengambilan sampel penelitian menggunakan non-probability sampling dengan teknik Cluster Sampling (Area Sampling). Arikunto (2013:182) (Area Sampling). kelas V SDN Gugus Patiunus Kecamatan Bonang Kabupaten Demak, meliputi beberapa hal yang akan dikaji. Hal yang akan dikaji meliputi: (a) uji normalitas data awal; (b) linieritas data awal; (c) uji multikolinieritas data awal; (d) uji korelasi sederhana data akhir; (e) uji korelasi ganda data akhir. kelas V SDN Gugus Patiunus Kecamatan Bonang Kabupaten Demak, meliputi beberapa hal yang akan dikaji. Hal yang akan dikaji meliputi: (a) uji normalitas 
data awal; (b) linieritas data awal; (c) uji multikolinieritas data awal; (d) uji korelasi sederhana data akhir; (e) uji korelasi ganda data akhir.

\section{UJI NORMALITAS}

Uji normalitas digunakan untuk mengetahui apakah data dalam penelitian berdistribusi normal atau tidak. Dari data yang diperoleh kemudian diuji normalitas menggunakan uji Kolmogorov-Smirnov dengan menggunakan bantuan SPSS seri 21. Kriteria pengambilan keputusan yaitu jika Signifikansi > 0,05 maka data berdistribusi normal, sedangkan jika Signifikansi $<0,05$ maka data berdistribusi tidak normal (Priyatno, 2013: 36).

Tabel 1 Uji Normalitas Angket

Kolmogorov-Smirnov ${ }^{\mathrm{a}}$

\begin{tabular}{lccc}
\hline & $\begin{array}{c}\text { Kolmogo } \\
\text { rov- } \\
\text { Smirnov }\end{array}$ & Df & Sig. \\
\hline Motivasi & & & \\
Belajar & .933 & 69 & $.348^{*}$ \\
Disiplin Belajar & 1.168 & 69 & $.130^{*}$ \\
Hasil Belajar & 1.179 & 69 & $.124^{*}$ \\
IPS & & & \\
\hline
\end{tabular}

Teknik pengumpulan data penelitian ini meliputi angket, wawancara, observasi, dan dokumentasi. Kuesioner merupakan teknik pengumpulan data untuk memperoleh informasi dari responden dengan cara mengisi pertanyaan atau pernyataan, yang kemudian dikembalikan kepada peneliti. Observasi dilakukan untuk mengetahui perilaku disiplin belajar siswa di sekolah. Teknik yang digunakan dalam wawancara tidak terstruktur sebagai data pendukung ini dilakukan dengan guru kelas V SDN Gugus Patiunus Kecamatan Bonang Kabupaten Demak. Metode dokumentasi dalam penelitian ini digunakan untuk mengumpulkan data tentang surat perijinan, dan data nilai IPS tengah semester 2 siswa kelas V SDN Gugus Patiunus Kecamatan Bonang Kabupaten Demak.
Analisis data penelitian ini berupa analisis data prasyarat dan analisis data akhir. Analisis data prasyarat meliputi uji normalitas uji linieritas dan uji multikolinieritas Analisis data akhir digunakan untuk menguji hipotesis yaitu uji korelasi sederhana dan uji korelasi ganda. Sebelum dilakukan uji korelasi sederhana, terlebih dahulu data diuji normalitas, uji linieritas dan uji multikolinieritasnya.

\section{HASIL DAN PEMBAHASAN}

Hasil penelitian tentang hubungan motivasi dan disiplin belajar dengan hasil belajar IPS siswa. Berdasarkan data hasil penelitian diperoleh nilai probabilitas untuk motivasi sebesar 0,933, disiplin belajar sebesar 1,179, dan hasil belajar IPS sebesar 1,179. Ketiganya memiliki nilai probabilitas $>0,05$ yang berarti data berdistribusi normal.

\section{UJI LINIERITAS DATA AWAL}

Uji linieritas data dilakukan setalah data diketahui berdistribusi normal. Apabila data tidak berdistribusi normal, maka tidak perlu dilakukan uji linieritas. Uji linieritas dilakukan untuk mengetahui terdapat hubungan yang linier antara $\mathrm{X} 1$ dan $\mathrm{Y}$ maupun X2 dan Y. Uji linieritas digunakan sebagai prasyarat sebelum melakukan uji hipotesis dengan menggunakan uji korelasi Product Moment.. Berikut hasil uji linieritas dengan bantuan SPSS 21.

Tabel 2 Hasil Uji Linieritas Data Awal

\begin{tabular}{cccc}
\hline Keterangan & Sig & Alpha & Kesimpulan \\
& & & \\
\hline X1 dan Y & 0,000 & 0,05 & Linier \\
X2 dan Y & 0,003 & 0,05 & Linier \\
\hline
\end{tabular}

Nilai signifikansi untuk linieritas variabel motivasi (X1) dengan hasil belajar IPS (Y) sebesar 0,000. Berdasarkan hasil analisis tersebut dapat dilihat bahwa signifikansi kurang dari 0,05 maka dapat disimpulkan bahwa antara variabel motivasi (X1) dengan hasil belajar IPS 
(Y) terdapat hubungan yang linier. Nilai signifikansi untuk variabel disiplin belajar (X2) dengan hasil belajar IPS (Y) sebesar 0,003. Berdasarkan hasil analisis tersebut dapat dilihat bahwa signifikansi kurang dari 0,05 maka dapat disimpulkan bahwa antara variabel linieritas variabel disiplin belajar (X2) dengan hasil belajar IPS (Y) terdapat hubungan yang linier.

\section{UJI MULTIKOLINIERITAS}

Uji multikolinieritas digunakan untuk menguji ada tidaknya hubungan yang linier antara variabel bebas yang satu dengan variabel bebas lainnya. Dalam uji multikolinieritas menuntut bahwa antar variabel $\mathrm{X}$ tidak boleh ada korelasi yang sangat tinggi, yaitu apabila harga

Untuk menghitung multikolinieritas menggunakan korelasi product moment guna menghitung korelasi antar variabel X. Dalam perhitungan ini uji multikolinieritas dihitung dengan bantuan SPSS versi 21 sehingga untuk mengetahui ada tidaknya multikolinieritas dapat dideteksi dengan melihat nilai VIF dan nilai toleransinya (Tolerance value). Apabila VIF di bawah 10 dan nilai toleransinya di atas 0,10 dan nilai keduanya mendekati 1 artinya tidak terjadi hubungan multikolinieritas maka variabel independen yang digunakan terlepas dari permasalahan multikolinearitas.

Tabel 3 Hasil Uji Multikolinieritas

\begin{tabular}{ccc}
\hline Model & \multicolumn{2}{c}{ Collinearity Statistics } \\
\cline { 2 - 3 } Motivasi & Tolerance & VIF \\
& 0.616 & 1.623 \\
& & \\
Disiplin Belajar & 0.616 & 1.623 \\
\hline
\end{tabular}

Dari hasil perhitungan diperoleh nilai VIF sebesar 1,623 (di bawah 10) dan nilai toleransi sebesar 0,616 (di atas 0,10) dan keduanya mendekati nilai 1 maka artinya tidak terjadi hubungan multikolinieritas antara variabel motivasi $\left(\mathrm{X}_{1}\right)$ dan variabel disiplin belajar $\left(\mathrm{X}_{2}\right)$.

\section{UJI KORELASI SEDERHANA}

Analisis uji hipotesis digunakan untuk menguji hipotesis penelitian yang telah diajukan dalam penelitian ini. Dalam penelitian ini, peneliti menggunakan rumus korelasi Product Moment.

Tabel 4 Hasil Korelasi Sederhana

\begin{tabular}{ccccc}
\hline Ket & $\begin{array}{c}\text { Sig(2- } \\
\text { tailed) }\end{array}$ & $\begin{array}{c}\text { Pearson } \\
\text { Corellati } \\
\text { on }\end{array}$ & $\begin{array}{c}\mathrm{T} \\
\text { tabel }\end{array}$ & Ket \\
\hline X1 dan Y & 0,000 & 0,683 & 0,244 & Kuat \\
X2 dan Y & 0,000 & 0,663 & 0,244 & Kuat \\
\hline
\end{tabular}

Pada variabel motivasi dengan hasil belajar

IPS dasar harga $\boldsymbol{R}_{\text {hitung }}$ sebesar 0,683, sedangkan $\boldsymbol{R}_{\text {tabel }}$ sebesar 0,244 pada taraf signifikansi 5\% dengan $\mathrm{N}=69$, maka $\mathrm{Ha}$ diterima. Jadi kesimpulannya terdapat hubungan yang positif dan signifikan, nilai koefisien korelasi gaa belajar dengan hasil belajar IPS yaitu sebesar 0,683 yang berada pada kritria kuat. Pada variabel disiplin belajar dengan hasil belajar IPS terdapat hubungan yang positif dan signifikan, nilai koefisien korelasi disiplin belajar dengan hasil belajar IPS yaitu sebesar 0,663 berada pada kriteria kuat.

\section{UJI KORELASI GANDA}

Analisis korelasi ganda digunakan untuk mengetahui hubungan antara dua atau lebih variabel independen terhadap variabel dependen secara serentak. Koefisien ini menunjukkan seberapa besar hubungan yang terjadi antara variabel independen dengan variabel dependen. Hasilnya dapat dilihat berikut ini.

Tabel 5 Hasil Uji Korelasi Ganda

\begin{tabular}{ccccc}
\hline Ket & $\mathrm{R}$ & $\begin{array}{c}\mathrm{R} \\
\text { Squere }\end{array}$ & $\begin{array}{c}\text { Adjusted } \\
\text { R Squere }\end{array}$ & $\begin{array}{c}\text { Std. } \\
\text { Error }\end{array}$ \\
\hline $\begin{array}{c}\text { X1 dan X2 } \\
\text { dengan Y }\end{array}$ & 0,748 & 0,560 & 0,546 & 6.091 \\
\hline
\end{tabular}

Tabel 5 menunjukkan bahwa harga Rhitung sebesar 0,748, sedangkan Rtabel sebesar 0,244 pada taraf signifikansi $5 \%$ dengan $\mathrm{N}=69$. Jadi kesimpulannya terdapat hubungan yang positif dan signifikan antara motivasi dan disiplin belajar dengan hasil belajar IPS, nilai koefisien korelasi ganda sebesar 0,748 yang berada pada kriteria kuat. 


\section{SIMPULAN}

Hasil penelitian menunjukkan bahwa ada hubungan yang signifikan antara motivasi dan disiplin belajar dengan hasil belajar IPS dengan kriteria kuat. Hal ini tunjukkan dengan perolehan nilai $\boldsymbol{R}$ hitung $>$ Rtabel yaitu $0,748>0,244$. Harga signifikansi $0,000<0,05$ yang berarti terdapat hubungan yang signifikan antara motivasi dan disiplin belajar dengan hasil belajar IPS.

Dengan demikian hipotesis penelitian ini diterima yaitu ada hubungan yang signifikan motivasi dan disiplin belajar dengan hasil belajar IPS siswa kelas V SDN Gugus Patiunus Kecamatan Bonang Kabupaten Demak.

\section{UCAPAN TERIMA KASIH}

Penulis mengucapkan terimakasih kepada kedua orangtua yang telah memberikan doa dan dukungannya, kepada dosen pembimbing 1 Dra. Munisah, M.Pd. dan dosen pembimbing 2 Dra. Kurniana Bektiningsih, M.Pd. yang telah membimbing sehingga artikel ini dapat terselesaikan., kepada Kepala Sekolah, guru dan siswa kelas V SDN Gugus Patiunus Kecamatan Bonang Kabupaten Demak, yang telah memberikan ijin melaksanakan penelitian dan telah berpartisipasi pada penelitian ini.

\section{DAFTAR PUSTAKA}

Arikunto, Suharsimi. 2013. Prosedur Penelitian Suatu Pendekatan Praktik. Jakarta: Rineka Cipta.

Desiyantina Ira, Djasmi Sultan dan Suharman Maman. 2015. Hubungan Antara Disiplin dan Kemandirian Belajar dengan Prestasi Belajar IPS, Mahasiswa FakultasKeguruan dan Ilmu Pendidikan Universitas Lampung. Bandar Lampung. 2015.
Sardiman. 2016. Interaksi \& Motivasi Belajar Mengajar. Jakarta : Rajawali Pers.

Uno Hamzah. 2015. Teori Motivasi \& Pengukurannya. Jakarta : PT Bumi Aksara.

Sari Rahmawati Indah Permata. 2014 Hubungan Motivasi Belajar Dengan Hasil Belajar Siswa Pada Mata Pelajaran IPS Kelas IV di SDN 11 Petang Jakarta, Tahun 2014.

Simba Nicholas Odoyo, Agak John Odwar and Kabuka Eric K. 2016. Impact of Discipline on Academie Performance of Pupils in Public Primary schools in Muhoroni Sub-Country, Kenya. Journal of Education and Practice. Vol.7, No.6, 2016.

Sugiyono. 2015. Metode Penelitian Pendidikan (Pendekatan Kuantitatif, Kualitatif, dan $R \& D)$.

Bandung: Alfabeta.

Sunandi, Sri dkk. 2014. Hubungan Antara Motivasi Belajar Dengan Prestasi Belajar Siswa SD Kelas V Semester Ganjil Di Desa Buruan. Jurnal Mimbar PGSD. 2 (1),1-10.

Slameto. 2010. Belajar dan Faktor-faktor yang Mempengaruhi. Jakarta : PT Rineka Cipta

Suardana Gde. Wiarta dan Sujana. 2014. Hubungan Antara Interpersonal Inteligence dan Motivasi Belajar Dengan Hasil Belajar IPS Siswa Kelas V SDN Gugus Letkol I Gusti Ngurah Rai Denpasar. Bali. Jurnal Mimbar PGSD Universitas Pendidikan Ganesha.. Vol.2, No.1, 2014.

Susanto, Ahmad. 2013. Teori Belajar dan Pembelajaran. Jakarta : Prenadamedia Group.

Sugiyono, 2007. Statistika Untuk Penelitian. Bandung: Alfabeta.

Tu'u, Tulus. 2004. Peran Disiplin pada Perilaku dan Prestasi Siswa. Jakarta: Grasindo 